University of Chicago Law School

Chicago Unbound

Journal Articles

Faculty Scholarship

2002

\title{
Let 'the Fundamental Things Apply': Necessary and Contingent Truths in Legal Scholarship
}

Richard A. Epstein

Follow this and additional works at: https://chicagounbound.uchicago.edu/journal_articles

Part of the Law Commons

\section{Recommended Citation}

Richard A. Epstein, "Let 'the Fundamental Things Apply': Necessary and Contingent Truths in Legal Scholarship," 115 Harvard Law Review 1288 (2002).

This Article is brought to you for free and open access by the Faculty Scholarship at Chicago Unbound. It has been accepted for inclusion in Journal Articles by an authorized administrator of Chicago Unbound. For more information, please contact unbound@law.uchicago.edu. 


\title{
LET "THE FUNDAMENTAL THINGS APPLY": NECESSARY AND CONTINGENT TRUTHS IN LEGAL SCHOLARSHIP
}

\author{
Richard A. Epstein*
}

\section{LEGAL INCREMENTALISM OR GRAND THEORY?}

This Symposium is devoted to understanding methods and trends in legal scholarship. At one level, there is very little new to report. Huge portions of legal scholarship as practiced in the academy are devoted to the routine tasks of lawyers. Nothing that we say or write here will, or should, alter the brute fact that much academic scholarship services the internal operations of the legal profession. Astute trial and appellate lawyers seek to modify legal doctrine to advance their own cases; judges try to sort out sound from spurious claims; and legal scholars chronicle the development of law in both its positive and normative dimensions. Lawyers revise restatements, draft legislative reports, and write academic critiques of judicial decisions and legislative and administrative programs. They take as given the fundamental premises of the system, whether explicit or implicit, and then seek to work out their implications in new areas, such as railroads and oil and gas in the nineteenth century or the electromagnetic spectrum and cyberspace in the twentieth. ${ }^{1}$

In discharging their professional obligations, lawyers usually examine social theory not as an end in itself, but as one means among many to resolve those interstitial cases that crop up in any system of rules. Lawyers use social policy to smooth out a statute with some roughness about its edges or to tie together a line of cases that does not otherwise connect. One classic illustration of this technique is the mimeographed Hart and Sacks materials on the legal process, which begins a general analysis of contract law with the question of who took the risk of loss for some spoiled cantaloupes. ${ }^{2}$ Indeed, much of my own early scholar-

* James Parker Hall Distinguished Service Professor of Law, University of Chicago Law School; Peter and Kirsten Bedford Senior Fellow, The Hoover Institution.

1 For a more complete articulation of this view, see Richard A. Posner, The Decline of Law as an Autonomous Discipline: 1962-87, 100 HARV. L. REV. 761 (1987).

2 Henry M. HART, JR. \& Albert M. SACKS, The Legal PROCESS: BasiC PRoblems IN THE MAKING AND APPLICATION OF LAW ro-75 (tent. ed. 1958). 
ship on such issues as the meaning of causation ${ }^{3}$ or the definition of income under the Internal Revenue Code ${ }^{4}$ falls into this mode.

Yet legal scholarship cannot be confined to housekeeping duties. Alongside the task of organizing law from the inside lies the task of situating it within a larger system of social relations. The political philosopher can ask questions about the legitimacy of legal rules or the definition of rights and duties. The economist can ask questions regarding the impact of legal rules on everything from the size of the GDP to the operation of financial markets or the rate of growth in socialist economies. A rich literature addresses how to think about law writ large, but lawyers have not written much of it. Indeed, many legal philosophers have echoed Immanuel Kant in censuring the lawyer for his philosophical ignorance, even on incremental matters of legal reform: "His office is only to apply positive laws, not to inquire whether they might not need improvement."5

The most tempting generalization to make about the evolution of legal analysis over the past thirty or forty years is that the rickety wall that once separated the internal from the external analysis of law has crumbled. As the argument goes, lawyers, especially academic lawyers, are no longer content to occupy themselves with the incremental elaboration of doctrine; in ever larger numbers, they have taken it upon themselves to analyze the fundamental building blocks of the social system, appropriating unto themselves all the tools of the philosopher, economist, and sociologist, and increasingly, those of the statistician, psychologist, and evolutionary biologist as well. Law has moved from an untheorized discipline, preoccupied with doctrine, to a more academic study that focuses on the principles underlying the legal system. This view is, for example, the one that Richard Posner takes in this issue. ${ }^{6}$

It is important, however, not to overstate the extent of this shift. Of course, the character and tone of much modern legal scholarship would have been unrecognizable to distinguished legal scholars before I960. But this transformation is hardly unique to the law, nor driven by the supposed intellectual provincialism of its earlier practitioners. A glance at either the American Economic Review or the Journal of Political Economy, for example, shows that an equally profound transformation has taken place within the economics profession over the

3 Richard A. Epstein, A Theory of Strict Liability, 2 J. LEgAL STUd. 15 I (1973).

4 Richard A. Epstein, The Consumption and Loss of Personal Property Under the Internal Revenue Code, 23 STAN. L. REV. 454 (I97 I).

5 Immanuel Kant, Perpetual Peace 34 (Lewis White Beck trans., Liberal Arts Press 1957) (1795). Kant followed this observation with a plea that kings in power should "not only suffer the class of philosophers to disappear or be silent, but should let them speak openly." Id.

6 Richard A. Posner, Legal Scholarship Today, I 5 HARV. L. REV. 1314 (2002). 
past forty years. The entire field has become far more mathematical in its orientation, and game theory has supplanted traditional price theory as the prevalent mode of analysis. ${ }^{7}$ Developments in anthropology, sociology, literature, and feminist theory suggest equally profound internal transformations in these disciplines over this period.

Viewed in light of these transformations, the concept that best captures the relationship of law to its contiguous disciplines is that of social lag. Both in earlier times and today, intellectual developments from other disciplines have taken time to work themselves sensibly into the fabric of the law. Sorting out the useful from the curious, erroneous, or irrelevant takes time. It is therefore quite natural for a five- to ten-year lag to separate the birth of an idea in a collateral discipline from its ultimate incorporation into legal scholarship. We should therefore expect legal scholarship today to have a different look and feel from the one it had two generations ago, even if the quantity of interdisciplinary work were as great then as it is now. Such may well be the case. Earlier legal writers were concerned not only with doctrinal analysis, but also deplored, as did Roscoe Pound, ${ }^{8}$ the use of mechanical jurisprudence when a more sociological jurisprudence lay near at hand. The use of the "Brandeis brief" to impart social science information, in such cases as Muller $v$. Oregon, ${ }^{9}$ represented a conscious effort by avant garde elements of the legal profession to inject social science into legal determinations in order to uphold such (dubious) legislation as sex-based hour and wage laws. Indeed, the entire dispute over the economic regulation of the workplace during the somewhat misnamed Lochner era injected into legal debates social science issues concerning the comparative strengths of regulated and unregulated labor markets. ${ }^{10}$

The same attitude, I think, characterized the common law. To give but one example, the English judges of the late nineteenth century had a very keen appreciation of the economic principles governing market behavior. In Printing \& Numerical Registering Co. v. Sampson,11 Lord Jessel deftly expressed the economic rationale supporting free-

7 See, e.g., Drew R. Fudenberg \& Jean Tirole, Game Theory (ig9i); Roger B. MYERSON, GAME THEORY: ANALYSIS OF CONFLICT (Ig9I). For an illustration of the influence these developments have had on legal scholarship, see DOUGLAS G. BAIRD, ROBERT H. Gertner \& RANDAl C. Picker, Game Theory aND the LAW (I994).

8 See Roscoe Pound, Mechanical Jurisprudence, 8 ColUM. L. REV. 665 (1908); Roscoe Pound, The Need of a Sociological Jurisprudence, Ig GREEN BAG 607 (I907).

9208 U.S. 412 (I 908 ).

10 See Lochner v. New York, I98 U.S. 45 (1905). Far from acting as a superlegislature, the Lochner Court was largely concerned with preventing class legislation. See HOWARD GILLMAN, The Constitution Besieged: The Rise and Demise of lochner ERA Police POWERS JURISPRUDENCE IO (1993).

11 I9 L.R.-Eq. 462 (Eng. Ch. 1875). 
dom of contract. ${ }^{12}$ Baron Bramwell, no insubstantial defender of laissez-faire, delivered the following accurate account of the modern standard of social welfare as early as 1862 in Bamford $v$. Turnley:13

The public consists of all the individuals of it, and a thing is only for the public benefit when it is productive of good to those individuals on the balance of loss and gain to all. So that if all the loss and all the gain were borne and received by one individual, he on the whole would be a gainer. ${ }^{14}$

Far from being untheorized, this account could scarcely have been articulated better by Pareto himself.

I have a similar, measured reaction to Deborah Rhode's renewed suggestion that lawyers engage in more empirical research about the actual operation of the legal system. ${ }^{15}$ Calls of this sort have been made from time out of mind, and they are always subject to the same objection: The division of labor matters, and lawyers qua lawyers have no comparative advantage in doing empirical work. As such, their preferred strategy should be to rely on the empirical work done by trained social scientists, or in the alternative, to spend time and effort acquiring the expertise needed to do social science work at their level (an investment that requires either specialized coursework or, more often, a Ph.D.). Lawyers should be able to understand, interpret, and critique the work of social scientists, not replicate it.

In this Essay, however, I am less concerned with the causal determinants of legal scholarship, classical or modern, and more with its intellectual styles. Over the broad sweep of time, these styles have fallen roughly into two categories, both of which are very much in evidence today. Their initial appearance, however, long predates modern innovations in legal scholarship. I will call the first the necessary side of legal thought and the second the contingent side of legal thought. These terms are closely akin to deductive and empirical, but the correspondence is not perfect. Necessary arguments cover not only truths that are logically necessary, but also those that invoke universal laws of human conduct analogous to the universal (for example, Newtonian) laws of physics. Contingent arguments exclude universal, if empirical, principles of behavior, focusing instead on social science paradigms that seek to understand the varieties of human behavior at a much lower level of generality. The central pursuit of legal studies, I con-

12 Id. at 465-66. For the other side of the debate on standard form contracts, see Friedrich Kessler, Contracts of Adhesion - Some Thoughts About Freedom of Contract, 43 CoLUM. L. REV. 629 (1943).

13122 Eng. Rep. 27 (Ex. 1862).

14 Id. at 32 .

15 Deborah Rhode, Legal Scholarship, i I5 HARV. L. REV. 1327 (2002). 
clude, involves identifying and weighing the tradeoffs that are everywhere implicit in the choice of legal rules.

\section{The Necessary SIDE OF THE LegaL Tradition}

The logical status of certain basic propositions has long been a central concern of analytical philosophers. On this issue, the debate generally focuses on the distinction, made explicit by Hume, between necessary and contingent truths. ${ }^{16}$ The former are true because to deny them entails self-contradiction. The latter are true (or false) because of the correspondence between the assertion and the state of affairs (or lack thereof) in the external world. Examples of logical truths include the contrapositive rule - if $p$ implies $q$, then not- $q$ implies not- $p$ and the statement that, given the definition of natural numbers, $2+2$ $=4$, and not 5 . The remaining truths are contingent and include Abraham Lincoln's date of birth, the law of universal gravitation, the atomic number of oxygen, and the number of books contained in the Library of Congress.

Where, then, do we locate legal propositions about the rights and duties of ordinary individuals? The necessary tradition promotes these propositions by treating them as though they could be denied only at the cost of self-contradiction. Thus, the natural law tradition frequently refers to "immutable" accounts and timeless principles of right and wrong. In many cases, this mindset leads to the defense of strong libertarian-like principles, so that it becomes impossible to deny respect for individual autonomy in the original position or to contest the view that each person has a right to be free from aggression. The somewhat mysterious word that is used to capture this approach to legal subject matter is "deontological." The clear goal of this enterprise is to strip legal propositions of what many call their "contestable" character by treating them as though they were necessary consequences of what it means - note the conscious equivocation between semantic meaning and social significance - to be a human being.

In some cases, the effort to build a necessary tradition does not appeal to general principles of logic, but rather works by imitating the universal laws of (Newtonian) physics. This influence is prominent in the jurisprudential portions of Blackstone's Commentaries, in which he quite consciously stresses the shared principles that animate all forms of law: "Law, in its most general and comprehensive sense, signifies a rule of action; and is applied indiscriminately to all kinds of action, whether animate or inanimate, rational or irrational."17 After

163 David hume, A TReatise of Human Nature $\$$ i, at 459-70 (L.A. Selby-Bigge ed., Clarendon Press 1888) (1739).

17 I William Blackstone, COMMENTARIES ON THE LAWS OF ENGLAND *38. 
noting that these laws of the creator include the laws of motion as well as the laws of animal and vegetable life, Blackstone argues that:

[W] hen [God] created man, and endued him with freewill to conduct himself in all parts of life, he laid down certain immutable laws of human nature, whereby that freewill is in some degree regulated and restrained, and gave him also the faculty of reason to discover the purport of those laws. ${ }^{18}$ It is often overlooked that this attitude, stripped of its theological foundations, animates much of the sprawling utilitarian tradition. Thus Elie Halévy brackets contemporaries John Locke and Isaac Newton as follows:

What is known as Utilitarianism, or Philosophical Radicalism, can be defined as nothing but an attempt to apply the principles of Newton to the affairs of politics and morals.

In this moral Newtonianism the principle of the association of ideas and the principle of utility take the place of the principle of universal attraction. ${ }^{19}$

The term "law" thus straddles the ground between those two hardy contemporaries, the universal law of gravitation and the Statute of Frauds.

The great difficulty in this quest to discern universal legal principles stems from the level of variation one encounters among the legal rules governing different societies. This variation leads the sociological thinker to deny that this level of universality can be found in any set of legal rules: It is well understood that the positive law in any jurisdiction can differ materially from the law in any other jurisdiction, so that those in the tradition of John Austin systematically reject the view that the pedigree of a law can be determined by the content, good or evil, of its commands. ${ }^{20}$ Instead, the operative principle is whether a given rule-like statement is one that has been made into law by the accepted processes of legislation and adjudication within any community that operates under the control of a common sovereign. ${ }^{21}$ Who speaks determines the legal force of what is said. There is no more logical contradiction in saying that a particular law is immoral than there is

18 Id. at *39-40.

19 Elie halevy, The Growth of Phnosophic Radicalism 6 (Mary Morris trans., 1972) (1928). Halévy then notes, correctly in my view, that there is little of the explicit utilitarian tradition in Locke; Halevy, however, locates the tradition in the work of Locke's immediate successors. On the historical connection between natural law and utilitarianism, see N.E. SIMMONDS, THE DECLINE OF JURIDICAL REASON: DOCTRINE AND THEORY IN THE LEGAL ORDER 56-59(1984), which notes that natural lawyers regard the utility of social rules as evidence of their divine origin. The same connection between utility and divinity is evident in William Paley; The PRinciples of MORal and Political Philosophy (Richardson \& Lord 1825) (1785), as discussed in HALEVY, supra, at 22-23.

20 John AUSTIN, The Province Of JURISPRUdence Determined (1832).

21 See H.L.A. HART, THE CONCEPT OF LAW 97-107 (2d ed. r994). 
in saying that societies governed by immoral laws will fare less well than societies governed by moral laws. The so-called separation of law and morals defended by traditional legal positivists such as H.L.A. Hart does not deny the possibility of a moral critique of existing social institutions; quite the opposite, it invites that critique by those who wish to reform the system from within or, in rarer cases, are willing to overthrow the system from without. ${ }^{22}$

The separation of law and morals requires both critics and defenders of the status quo to develop some substantive normative ground from which to defend their positions - a development that, as I argue later, quickly forces both sides into a consequentialist dialogue. But even before we enter into that debate, one point should be clear: the effort to ground any legal system on necessary truths, whether by analogy to logic or to the physical sciences, must fail in its essential mission.

The effort to produce knockdown victories in the analysis of legal rules is not confined to those (largely conservative) writers who defend the common law synthesis of legal rights and duties as the normative benchmark for legal analysis. The same strategy was adopted for different ends by the leaders of the Critical Legal Studies (CLS) movement, which assumed great prominence in the r970s and r980s but has, as best one can tell, withered away in the past decade. The leitmotif for CLS is the socialist concern with the "contradictions of capitalism." In using this phrase, the supporters of CLS were after larger fish than James Boyd White seeks to fry in his essay Legal Knowledge, which addresses the "tensions and contradictions" that lie close to the core of the Model Penal Code. ${ }^{23}$ It may well be that the Code does not make clear the role of mens rea with respect to each element of all offenses, so that it is an open question whether a given interpretive community believes that a rape defendant can be convicted only if he has subjective knowledge of the victim's lack of consent. Issues of this sort are critical in some litigated cases, but they can be laid to rest by a clearer articulation of the statutory standard, or in the alternative, by an authoritative judicial decision one way or the other.

In contrast, the contradictions that preoccupy the CLS movement cannot be resolved by such handy means. Working in this larger arena, CLS scholars, like the champions of natural law, think that the battle over ideas could be waged with deductive truths. Much of the impetus for this movement came from Duncan Kennedy's seminal piece, Form and Substance in Private Law Adjudication. ${ }^{24}$ It is no

\footnotetext{
22 See, e.g., id. at $185-212$.

23 James Boyd White, Legal Knowledge, i 5 HARV. L. REV. 1396, I410 (2002).

24 Duncan Kennedy, Form and Substance in Private Law Adjudication, 89 HARV. L. REv. I685 (1976).
} 
surprise that the first footnote in that article cites the Hart and Sacks materials, which were the exemplar of standard business practices. ${ }^{25}$ Kennedy opens by asserting the "contradiction" within the legal order that arises from the fundamental tensions between rules and standards or between individualism and altruism. ${ }^{26}$ The tone is sharpened because the term "contradiction" frames the entire discussion, which is just how Mark Kelman explicates the problem when he launches his book $A$ Guide to Critical Legal Studies with the following analysis of traditional legal scholarship:

The descriptive portrait of mainstream liberal thought that I present is a picture of a system of thought that is simultaneously beset by internal contradiction (not by "competing concerns" artfully balanced until a wise equilibrium is reached, but by irreducible, irremediable, irresolvable conflict) and by systematic repression of the presence of these contradictions. ${ }^{27}$

Just what are these contradictions? Here let me mention just the first two:

(I) the contradiction between a commitment to mechanically applicable rules as the appropriate form for resolving disputes (thought to be associated in complex ways with the political tradition of self-reliance and individualism) and a commitment to situation-sensitive, ad hoc standards (thought to correspond to a commitment to sharing and altruism).

(2) the contradiction between a commitment to the traditional liberal notion that values or desires are arbitrary, subjective, individual, and individuating while facts or reason are objective and universal and a commitment to the ideal that we can "know" social and ethical truths objectively (through objective knowledge of true human nature) or to hope that one can transcend the usual distinction between subjective and objective in seeking moral truth. ${ }^{28}$

The resort to "contradictions" in CLS forms an odd couple when juxtaposed with the asserted "necessity" of natural law. Just as the proponents of natural law overreached themselves by appealing to deductive logic, CLS scholars exaggerate their claim by elevating every important remedial and institutional tradeoff into a contradiction worthy of Karl Marx's critique of capitalism generally. Necessity, impossibility, and contradiction are logical constructs, none of which is equipped to handle the messy materials of the law. Armchair empiricism is at times the best tool we have for resolving these matters. The language of competing concerns or, even better, that of tradeoff more

5 Id. at 1685 n.I (naturally).

26 Id. at 1685 ("The opposed rhetorical modes lawyers use reflect a deeper level of contradiction.").

27 MARK Kelman, A GUIDE TO CRITICAL Legal STUdies 3 (1987).

28 Id. 
suitably captures how the debate over remedial and institutional alternatives proceeds. At root, both the natural lawyers and their critical opponents are, at least in their less cautious moments, similarly misguided about the nature of the legal enterprise. In fact, a much more modest way to describe the same choice between legal rules addresses both contradictions asserted by CLS scholars.

With regard to the first contradiction, the legal system always has to make a choice between the adoption of hard-edged rules and more flexible standards. This distinction is most evident when the alternatives lie at each pole, but it is easy to imagine intermediate positions that combine both perspectives in a single statutory or common law program. Moreover, the approaches are in a sense mirror images: the advantages of each correspond to the weaknesses of the other. A moment's further reflection should indicate the impossibility of identifying a single dominant solution that uniformly favors either rules or standards. Thus, it is possible for a system of contract law to adopt something that looks like a hard-edged rule when it says that no promise shall be enforced unless it is supported by consideration, or that parties may enter into contracts at will in which either side can sever the relationship for good reason, bad reason, or no reason at all. At the same time, broadly speaking, the rule could enforce promises so long as there is detrimental reliance on them or specify that contracts for employment may be terminable only for cause. Likewise, in antitrust law, it is possible to regard certain offenses as per se illegal (at least as a first approximation, usually done with price fixing and market division), and others as subject to a rule of reason (often the approach applied to tie-ins and other vertical arrangements).

The key point here is that the choice of any rule has pluses and minuses, whose magnitudes will vary depending on the context. The rule of consideration narrows the scope of contractual enforcement by excluding such commercial promises as firm offers, certain contract modifications, and forgiveness of debts previously accrued. As such, it acts as a restriction on freedom of contract, which in my view is not justified by the ostensible advantage of narrowing the range of enforceable promises to those whose importance merits legal recognition. A release in writing, for example, could generally be fully enforceable. The renegotiation problem requires more detailed analysis, owing to the difficulty of determining whether the promisee has extracted some illicit gain from a promisor caught in a traditional bind, or whether the new promise simply reflects an unanticipated increase in costs that the promisor is willing to share, if only to keep the promisee from bank- 
ruptcy. ${ }^{29}$ Some borderline cases escape easy resolution, ${ }^{30}$ but experience indicates that, even when faced with such difficult questions, courts do a more than credible job in sorting out the cases on one side of the line from those on the other. ${ }^{31}$ There is no insoluble contradiction here - only a thorny problem that is resolved by applying bargaining theory in ways that reflect underlying business realities.

The same observation can be made with reference to antitrust law. As the recent Microsoft decision ${ }^{32}$ reminds us, there are good reasons why we do not use a per se rule when evaluating tie-in arrangements. ${ }^{33}$ A wide variety of firms, including many of Microsoft's competitors, use tie-in arrangements even when they possess no market power. The widespread adoption of these arrangements is strong evidence of their efficiency. In some cases, a tie-in arrangement helps to reduce the incidence of fraud by consumers. For example, when the seller of a product also provides installation, it is not possible for a consumer, who botched the installation, to claim that the product itself was defective. In other cases, the tie-in reduces the costs of jointly supplying goods that are used in fixed proportion to one another, so that shoes come with shoelaces, or indeed, left shoes with right ones. By the same token, the difficulty of devising plausible efficiency justifications for price fixing or territorial divisions justifies subjecting these arrangements to a per se rule. The sharing of information between competitors presents an intermediate case; notwithstanding a general presumption of illegality, the practice is sometimes permitted, either to prevent customer fraud ${ }^{34}$ or to facilitate business-to-business

29 See, e.g., Goebel v. Linn, II N.W. 284,285 (Mich. I882) (finding no opportunism when the price increase at issue reflected "extraordinary circumstances" that dramatically increased the cost of harvesting and shipping ice).

30 Compare, e.g., Alaska Packers' Ass'n v. Domenico, I 7 F. 99, I02 (9th Cir. 1902) (citing possible opportunistic behavior by fishermen in Alaska as a basis for voiding a corporation's agreement to pay them higher wages), with Douglas G. Baird, Self-Inierest and Cooperation in LongTerm Contracts, I9 J. LEGAL STUD. 583, 586-89 (1990) (noting that the nets provided to the fishermen might have been worse than either party expected and that, by enforcing the contract as written, the court might have assigned unallocated risk to the wrong party).

31 Compare, e.g., Angel v. Murray, 322 A.2d 630 (R.I. I 974) (noting the importance of the older preexisting duty rule to counter the "hold up game," but finding that the increases allocated in the case at bar reflected unanticipated increases in costs), with Austin Instrument, Inc. v. Loral Corp., 272 N.E.2d 533 (N.Y. 1971) (finding a hold up when a contractor was obliged to accept a price increase demanded by a subcontractor in order to receive components necessary to fulfill a military contract).

32 United States v. Microsoft, 253 F.3d 34 (D.C. Cir. 200I).

33 See id. at 89-95 (holding a per se analysis inappropriate for evaluating the defendant's tying arrangement).

34 See Cement Mfrs. Protective Ass'n v. United States, 268 U.S. 588 (1925) (permitting competitors to share price information to prevent fraud in certain limited cases). 
transactions. ${ }^{35}$ This is not the appropriate occasion to delve into the subtleties of antitrust law, except to say that the mere presence of a tradeoff on the horizon does not lead to fatal indeterminacy or logical contradiction. We may not have drawn the line in the right place, but at least we have avoided the acute embarrassment of getting things backward, for example, by favoring horizontal contracts for market division over vertical arrangements.

Likewise, it makes scant sense to associate rule-like statements with a profound commitment to individualism, and softer standards with altruistic values. For example, even in systems that dispense with the requirement of consideration, gift promises are only enforceable if the parties observe some level of formality. ${ }^{36}$ These systems use form as a hedge against overreaching in family situations by denying enforcement to promises made out of fatigue or exasperation. This strategy is not foolproof, but so long as these forms improve the odds of weeding out hasty and ill-considered promises, their use should be encouraged rather than frowned upon. Similarly, the broader doctrines of promissory estoppel are more consistent with freedom of contract than the hard-edged rule of consideration. ${ }^{37}$ Likewise, in antitrust law, the shift from a per se rule to a rule of reason regime was not motivated by altruism, but by the inability of fixed rules to distinguish restrictive from efficiency-enhancing arrangements. Finally, tradeoffs between precision in judgment and ease of measurement must be made in tort law as well. The current law generally favors a system of "pure" comparative negligence, whereby courts and juries go to great length to measure the precise causal contribution of each party to an accident. But by the same token, there is much to be said for the now discarded admiralty rule ${ }^{38}$ that simply splits the loss equally between the two parties. The relative ease of implementation reduces the costs of administration, while obviating the need for complex and unstable judgments on matters of degree. Under any regime, one pervasive question is whether the gains from allocating risk justify the additional costs of the process. In tort law, it is exceptionally difficult to come up with one dominant solution, which perhaps explains why so many different

35 In United States v. Citizens \& Southern National Bank, 422 U.S. 86 (1975), the Court noted that the "the dissemination of price information is not itself a per se violation of the Sherman Act" but that it creates only a prima facie case, which a defendant may rebut by showing some business need for the sharing of the information. Id. at II3. The Court proceeded to find that such a need was present when the dissemination was necessary to run a check-clearing operation. Id. at II4-I5.

36 Andrew Kull, Reconsidering Gratuitous Promises, 2 I J. LEgAL STUD. 39 (1992).

37 Richard A. Epstein, The Social Consequences of Common Law Rules, 95 HARV. L. REV. 1717, $1745-48$ (1982).

38 See, e.g., United States v. Reliable Transfer Co., 42 I U.S. 397 (1975) (rejecting the admiralty rule); Li v. Yellow Cab Co., 532 P.2d 1226 (Cal. I975) (same). 
versions of comparative negligence have been tried and found wanting. But in the midst of this vacillation, we are not concerned with either of the two dominant concerns of CLS: the law's internal contradictions or the tension between altruism and individualism. Rather, we can console ourselves with the observation that our inability to provide precise answers to hard questions may not matter that much in this context because not too much is at stake in the choice of legal rules. ${ }^{39}$

Finally, these tradeoffs in institutional design are not unique to a system of private law in the laissez-faire tradition. These tradeoffs are endemic to every piece of legislation of the modern state, regardless of its substantive content. Similar tradeoffs must be made in organizing every state-run cartel, enforcing every minimum wage law, subsidizing every agricultural crop, determining eligibility and payment in every public welfare program, and assigning the burden of proof in every modern discrimination, product liability, or securities action. The need to identify and resolve tradeoffs is endemic to all law, regardless of its social commands and legal objectives.

Kelman's second contradiction seems to have even less staying power than his first because it represents a simple confusion in thought. Skepticism comes in two forms. First, it may be used as a club to bludgeon any effort to systematize legal rules. Second, it may operate as a sensible constraint on the exercise of government power when the state claims to know the individual preferences of its citizens better than they know these preferences themselves. Here (in ways that I discuss later in connection with "relative preferences") it is generally a mistake for the state to second-guess people who say that they want beer by ordering them to drink milk instead. It may be sensible for the state to remonstrate with recalcitrant beer drinkers by offering them evidence of the foolishness of their choice, but it is dangerous to command them to do what is in their interests for their own protection. This principle represents the core of good sense in John Stuart Mill's famous (but incomplete) articulation of the harm principle ${ }^{40}-\mathrm{a}$

39 See Epstein, supra note 37 , at 1724 .

40 Mill explained the harm principle as follows:

That principle is, that the sole end for which mankind are warranted, individually or collectively, in interfering with the liberty of action of any of their number, is selfprotection. That the only purpose for which power can be rightfully exercised over any member of a civilised community, against his will, is to prevent harm to others. His own good, either physical or moral, is not a sufficient warrant. He cannot rightfully be compelled to do or forbear because it will be better for him to do so, because it will make him happier, because in the opinions of others, to do so would be wise, or even right. These are good reasons for remonstrating with him, or reasoning with him, or persuading him, or entreating him, but not for compelling him, or visiting bim with any evil in case he do otherwise. 
core that remains critical notwithstanding the formidable difficulties in isolating what kinds of actions affecting others should count as harm. ${ }^{41}$

The application of the harm principle thus presents delicate questions of whether we should, for example, use the same set of rules to treat physical injury and competitive harms. In answering these questions, we have to address the usual set of tricky empirical tradeoffs and to ask whether we have sufficient information to distinguish one legal state of affairs from another. Surely, it makes some difference that competition generally has positive social effects while the use of physical force does not. This reliance on broad consequential judgments often incurs the wrath of writers in the Kantian tradition. George Fletcher, for example, has observed that the adoption of the Kaldor-Hicks conception of efficiency, under which the possibility of compensation is sufficient to justify the forced transfer of an asset from $A$ to $B$, opens the door to a massive use of state power against which Kantian theories supply an appropriate bulwark. ${ }^{42}$ But this observation, even if true, should hardly drive us away from the domain of tradeoffs. Rather, it only suggests that the more stringent Pareto standard, which requires no one to make sacrifices for the good of others, is of greater appeal to Kantians, indeed, to the community at large. But when this standard is applied in practice, someone must judge whether the tradeoffs behind forced exchanges do in fact lead to Pareto improvements. In practice, moreover, the difference between the two standards may be overstated. Even the Kaldor-Hicks standard does not endorse forced transfers willy-nilly. It blocks (as does the Pareto standard) all transactions that produce net social losses, and it leaves open the question whether the failure to require compensation in individual cases will invite interested parties to enter into more transactions that create net social loss. Nor is it valid to suppose, as Fletcher does, that we find little occasion for legal intervention until we switch from Pareto to Kaldor-Hicks efficiency because law is generally used for "coercive interventions that make some people worse off." 43 This statement confuses the ex ante with the ex post perspective. From the ex ante perspective, forced exchanges are often necessary to reach states of the world that people will not reach voluntarily because transaction costs are too high. Coercion is thus justified under the Pareto standard to ensure that no one defects from the arrangement ex post. Indeed, I believe that the only way that one can make

JOHN STUART MILL, On Liberty, in UTILITARIANISM, LIBERTY AND REPRESENTATIVE GOVERNMENT 72-73 (Ernest Rhys ed., J.M. Dent \& Sons 1929) (1910).

41 For my explication, see RICHARD A. EPSTEIN, PRINCIPLES For a FREE SOCIETY:

RECONCILING INDIVIDUAL LIBERTY WITH THE COMMON GOOD 7 I-103 (1998).

42 George P. Fletcher, Why Kant, 87 CoLUM. L. REV. 421, 425-26 (1987).

43 Id. at 425 . 
sense out of Kant is in consequentialist terms; he implicitly supports the Pareto standard when most of us are willing to let go - that is, in those cases in which the uncompensable loss to one individual is small, but the gains to everyone else are large. ${ }^{44}$ This reasoning can only prevail if we can form a general estimation that serious bodily harm is of greater concern to individuals than, say, some momentary insult or slight. And we can.

\section{SELF-INTEREST, COERCION, AND CONSENT}

The preceding discussion of subjective value offers a convenient bridge to examine the second of the two structural issues that legal scholarship must confront. Once it is clear that neither the language of (logical or scientific) necessity nor that of contradiction can either support or undermine the articulation of any set of legal rules, we must ask: what next? One option is to lapse into giddy skepticism that once nothing is certain, anything goes. This attitude frequently surfaced in the more extreme statements of some of the early legal realists. ${ }^{45}$ As a normative position, it offers at most thin gruel to judicial decisionmakers. As H.L.A. Hart pointed out long ago, however invigorating an outside observer might find it to celebrate the complete discretion of a judge to do whatever he pleases, that world view offers scant guidance or consolation for the judge charged with deciding cases by propounding rules in the first place. ${ }^{46}$ Therefore, we must determine how to avoid the twin shoals of excessive dogmatism and excessive skepticism.

We can chart a middle course by grounding legal rules in a clear, abstract, empirical understanding of human capabilities that then helps to explain human behavior in particular contexts. Here it is particularly important that we be careful in understanding the implications of skepticism. More concretely, it hardly follows from my earlier discussion that our skepticism about the shape of other people's preferences means that we objectively cannot "know" any social or ethical truths. Quite the opposite, our relative inability to second-guess the preferences of others offers a persuasive "second-order" reason to endorse a strong (but not absolute) institutional preference for consensual over forced exchanges; the legal system should find the former presumptively acceptable and the latter presumptively unacceptable. From this framework, we can mount a defense of private property and freedom of contract, subject to the usual provisos regarding the role of

44 See Immanuel Kant, The Metaphysics of Morals (Mary Gregor trans. \& ed., Cambridge Univ. Press I996) (1797).

45 See, e.g., K.N. LlewellyN, The Bramble BuSh: ON OUR LAW AND ITS STUdY 3 (Ig60).

46 See H.L.A. Hart, Scandinavian Realism, 1959 CAMBRIDGE L.J. 233 (critiquing the radical position of such Scandinavian Realists as Alf Ross). 
government in protecting individuals against the use of force and fraud, regulating monopoly, and providing public infrastructure. ${ }^{47}$

By way of illustration, consider that the use of public force always imposes a cost that has to be justified by the benefits it is able to procure. To evaluate these benefits, it is useful as a first approximation to partition the world into two halves - one engaged in voluntary transactions and the other in coercive transactions. Parties to voluntary transactions receive mutual gains that justify the use of state power to enforce such transactions. Unless these transactions are enforced, the parties will have a built-in incentive to renege (the bad side of self-interest again); recourse to state power at the back end of transactions gives private actors the confidence to enter them at the front end.

Coercive transactions produce quite different outcomes. The use of force results in gains for one side but losses for the other. There is no credible justification for the use of coercion under a Pareto standard. The story is somewhat more complex under a Kaldor-Hicks. standard, but only slightly so. In principle, one could argue that the gains to the winner from the use of force are so large that they justify the harms inflicted on the loser. Concluding that the losses always outweigh the gains requires an additional empirical judgment, but it is the kind of empirical judgment that just about everyone makes when comparing the devastation that murder and rape inflict on their victims with the evanescent gains that they yield to their perpetrators. One powerful use of the Rawlsian veil of ignorance (or for that matter the Golden Rule) is to explain the enormous appeal of the basic prohibition against aggression. Ask people to choose between two worlds when they do not know the place they will occupy in either. In the first world, each person renounces the use of force against another. In the second, that force is allowed, and when it is used, a given person has an equal probability of being victim or aggressor. Who would attach a greater expected value to the second world? The short answer is no one. One of the great mistakes of modern political thought has been to ignore the centrality of a collective response to the use of force and fraud. Before the tragic events of September I I, 200I, we labored under the illusion that we could take security in our bodies and possessions for granted, but reality turned out to be quite to the contrary.

The sharp line of distinction, then, between coercion and consent is that the latter yields positive-sum games while the former tends to yield negative-sum games. In light of this information, one possible strategy for legal thought to pursue would be to convert strong pre-

47 For a working definition offered by a critic of the system, see Jacob Viner, The Intellectual History of Laissez-Faire, 3 J.L. \& ECON. 45, 45-46 (1960). 
sumptions into absolutes and thus to cut off any serious inquiry into when either or both of these presumptions should be reversed. In my view, much of the development of modern legal thought has rested on innovations, chiefly introduced in the I960s, that for the first time established a strong theoretical basis for identifying those circumstances that justify overcoming the initial presumptions - that is, for limiting freedom of contract on the one hand and for allowing the use of collective force on the other. The distinguishing feature of these developments is not the complexity or subtlety of their arguments; all the basic points here are obvious, once they are identified, and powerful enough to be applied usefully in a wide range of social settings. The hallmark of these developments is that they force lawyers to abandon the centerpiece of the Socratic method: that is, deciding whether a marginal case or its countless variations fall on one side of an agreed-upon line or on the other.

\section{CRitical InNOVATions}

To shed light on what is at stake, I give a brief account below of what I consider the central innovations in disciplines collateral to law. Overall, I believe that we can glean important insights from this brief overview of the logical and empirical foundations of legal rules. For better and for worse, the structure of the academic legal marketplace exerts a powerful influence on the nature and direction of legal scholarship. The largest returns from scholarship rightly belong to those individuals who break the traditional mold and find genuinely new ways of analyzing legal materials.

In the high-risk search for innovation, however, we often forget Sam's great lesson in Casablanca: that "[t]he fundamental things apply." 48 In many ways, the greatest insights cut against the skeptical impulse. They are constructive, yet not naïve. Far from undermining our conventional institutions and practices, they help to explain the durable features of human life and social organization. In my view, the reason that legal scholarship in the last thirty or so years has looked so different from its predecessors is that it has built on fundamental innovations in collateral disciplines that took place in the I950s and I960s. I do not claim that these movements were brand new at their inception, for few intellectual developments of lasting merit are cut from whole cloth. Rather, in each case it is possible, in retrospect, to identify the antecedents that anticipated but did not fully capture the central insight. So here is my list of four innovations that enriched

48 Herman Hupfeld, As Time Goes By (Warner Bros. Music Corp. I93I), featured in CASABLANCA (Warner Bros. 1942). 
the way in which lawyers (and certainly this lawyer) think about legal problems and social institutions.

\section{A. Transaction Costs}

Transaction costs are to the legal system as friction is to physical systems. They are everywhere present, yet often ignored. The great insight Coase raised in his 1937 article The Nature of the Firm ${ }^{49}$ and later elaborated in his 1960 article The Problem of Social Cost ${ }^{50}$ is that we can go a long way toward explaining the structure of firms, partnerships, and other voluntary associations by understanding the devices they use to minimize transaction costs. Coase started with the common view that contracts are sources of mutual gain. He then advanced the key insight that voluntary exchanges cannot take place when the costs of arranging and executing the transactions exceed their anticipated gain. Coase's insight shapes a social agenda that structures legal rules and channels private behavior to minimize transaction costs in order to maximize the flow of voluntary transactions. Scholars use this framework to examine various strategies (formalities, recordation systems, guarantees, choices of substantive terms, default rules, and reputational bonds) to deal with transactional impediments to social improvement. Much of the analysis in defense of the contract at will, for example, can be understood in light of this framework.

\section{B. Public Goods and Common Pools}

Public goods and common pools are opposite sides of the same coin; both stem from mismatched fractional holdings of gains and losses. Mancur Olson's 1965 book The Logic of Collective Action ${ }^{51}$ demonstrated that markets will systematically underprovide certain public goods in a world with positive transaction costs; earlier work by $H$. Scott Gordon formalized the model of the overutilization of the common pool. ${ }^{52}$ In the case of public goods, actors internalize the entire cost of their actions, but only some fraction of their benefits. In the case of common pool problems, they internalize the entire benefit of their actions, but only some fraction of their costs. The common thread between these two problems is the mismatch between the share of costs individual actors bear and the share of benefits they receive. In many settings, these asymmetries justify some form of state intervention, even though none of the parties so regulated uses coercion against the others. The framework thus gives a principled explanation

49 R.H. Coase, The Nature of the Firm, 4 ECONOMICA 386 (1937).

50 R.H. Coase, The Problem of Social Cost, 3 J.L. \& Econ. I (1960).

51 ManCUR Olson, JR., The Logic OF COLleCtive ACTION (Ig65).

$52 \mathrm{H}$. Scott Gordon, The Economic Theory of a Common-Property Resource: The Fishery, $62 \mathrm{~J}$.

POL. ECON. I 24 (1954). 
for the justified use of force in ways that do not prevent the use of force or fraud by the parties so regulated. A system of collective taxation or assessments could in principle provide an antidote to the first problem described above, which affects the provision of public goods ranging from street lights to national defense. Likewise, collective restrictions on individual initiatives could prevent overfishing or overhunting of the commons. In all cases, the question is whether the costs of state intervention exceed the anticipated gains; huge differences in outcome depend on the fine-tuning of the overall system. ${ }^{53}$

\section{Public Choice}

The ordinary analysis of competition and monopoly presupposes that individuals pursue their own self-interest. But all too often this basic human impulse has been ignored in analyzing public officials' behavior. The public choice theory set forth in James Buchanan and Gordon Tullock's The Calculus of Consent ${ }^{54}$ asked how public institutions operate once the basic self-interest assumption is carried over from private to public actors. Buchanan and Tullock's systematic exploration of the dangers of faction under a wide variety of voting rules and administrative structures led to the unification of behavioral assumptions for actors in both the public and private sectors. It also helped to explain the role of constitutional structures in limiting the discretion of government actors and in constraining the dangers of faction. Vast areas of public, administrative, and constitutional law address the single question of what kinds of constitutional provisions can align the private incentives of public officials with the interests of overall social welfare.

The requirement that the state pay just compensation when it takes private property for public use falls neatly into this category. The prohibition not only taps into a strong intuition that it is unfair to require a single individual to bear the costs of providing benefits to society at large, but also offers a functional justification that supports the same conclusion. ${ }^{55}$ The state that does not have to pay for the private resources it consumes either will consume too many resources or provoke a fierce partisan struggle in which both public and private resources are spent to redirect the use of public force. The compensation requirement allows the state to take property for public use (notwithstanding any generalized prohibition against the use of force) on the

53 See R. Quentin Grafton, Dale Squires \& Kevin J. Fox, Private Property and Economic Efficiency: A Study of a Common-Pool Resource, 43 J.L. \& ECON. 679, 709-10 (2000) (using conventional economic analysis to explain the enormous productivity gains achieved by substituting an efficient system of regulation for an inferior one).

54 James Buchanan \& GoRdon Tullock, The Calculus of Consent (I962).

55 See Armstrong v. United States, 364 U.S. 40, 49 (1960). 
condition that it make payments that leave the party coerced at least as well off as he would have been in the absence of coercion. It thus offers a way to resolve the collective action problems described above without creating a governmental leviathan that wreaks more havoc that it eliminates. Scholars can adopt the same approach when analyzing the behavior of officers and directors in corporate, religious, and educational institutions to assess, for example, the role of the business judgment rule.

\section{Inclusive Fitness}

The standard accounts of self-interest focus only on the individual. More comprehensive biological accounts center on the gene. Starting with William Hamilton's insight that each organism takes into account the welfare of another in proportion to their common genes, it becomes possible to explain the complex relationships not only between parent and child, but also within more extended kinship arrangements. ${ }^{56}$ Robert Trivers's paper on parent-child conflicts of interest demonstrates that how these conflicts are resolved initially turns on whether the cost of care to the parent is greater or less than one half the benefit to the child. ${ }^{57}$ When the parental cost is less, the parent will bear that cost willingly because he or she regards one half the child's gain as greater than his or her own cost. But once the parental costs (for example, at the end of weaning) lie between one half and twice the benefit to the offspring, the offspring will want the action to continue while the parent will want to stop it. Finally, to complete the story, the conflict of interest disappears once the costs to the parent are more than twice the benefit to the child, for then neither will want the action to continue. The value of the biological theory is that it not only allows analysis to proceed beyond individual self-interest, but also explains the direction that analysis should take. We can view, for example, emotions (such as love between parent and child) as programmed in a manner calculated to maximize inclusive fitness. Accordingly, strong individualistic assumptions are tenuous within the context of the family, but are far more plausible in dealing with strangers. There is no personality disorder when a trader bargains hard with a stranger and then gives away his gains to his children.

Trivers's basic model, moreover, has strong parallels in the behavior of actors in business organizations. These conflicts are identical to those identified shortly thereafter by Jensen and Meckling in their de-

56 See W.D. Hamilton, The Genetical Evolution of Social Behaviour 1,7 J. THEORETICAL BIOLOGY I (1964); see also RICHARD DAWKINS, THE SELFISH GENE (2d ed. I989) (discussing the issue of genetic self-interest in relationships between organisms).

57 Robert L. Trivers, Parent-Offspring Conflict, I4 AM. ZoologisT 249 (1974). 
tailed discussion of the economic theory of agency cost. ${ }^{58}$ This discussion explored similar conflicts of interest between, for example, contingent fee lawyers and their clients or directors of a corporation and its shareholders. These conflicts are pervasive and give rise to the institutional challenges of reducing their impact through direct monitoring, specialized arrangements, or hiring and promotion strategies. A parallel concern with mismatched payoff structures, moreover, carries over to constitutional law, in which the "average reciprocity of advantage" is taken as a strong signal that a regulation can pass muster under the Takings Clause. ${ }^{59}$ Similarly, a content-neutral regulation is more likely to survive scrutiny under the First Amendment.60

It is instructive to note that the first three of these innovations build on the most basic model of individual self-interest, by extending it to new settings. They presuppose no psychological complexities. Highly conventional premises therefore yield some striking insights into the uses and limitations of both government and market structures. The fourth development, inclusive fitness, does expand the idea of self-interest, but this extension is grounded securely in basic biological considerations. All four innovations tend to work in concert to support a world in which the public use of force becomes justified largely to control aggression and to supply traditional public goods.

Many innovations in modern scholarship do not necessarily have this character, for they rely on constructs that are grounded neither in the basic model of individual self-interest nor in biological theory. The mistakes in analysis (if such they are) are not necessarily ones associated with any particular political point of view. As an illustration, contrast the standard biological models with Gary Becker's "rotten kid theorem," 61 which I think offers an implausible description of human behavior, even if it falls squarely within the framework of neoclassical economics. In Becker's model, parents care about the welfare of their children (also the biological position), but children are indifferent to the welfare of their siblings. This last assumption deviates from the

58 See Michael C. Jensen \& William H. Meckling, Theory of the Firm: Managerial Behavior, Agency Costs and Ownership Structure, 3 J. FIN. ECON. 305 (I976).

59 See $\mathrm{Pa}$. Coal Co. v. Mahon, 260 U.S. 393, 415 (1922) (recognizing "an average reciprocity of advantage" as a sufficient justification for various restrictions on common law rights); see also Armstrong, ${ }_{364}$ U.S. at 49 (holding that the just compensation requirement was designed to prevent the state from "forcing some people alone to bear public burdens"). The simple explanation for this distinction is that non-pro rata transfers typically lead to net wealth transfers that count as a taking of private property. See Richard A. EPSTEIn, TAKINGS: Private PRoperty AND THE POWER OF EMINENT DOMAIN 204-O9 (I 985 ).

60 See Geoffrey R. Stone, Content-Neutral Restrictions, 54 U. CHI. L. REV. 46, 57-80 (1987); Geoffrey R. Stone, Content Regulation and the First Amendment, 25 WM. \& MARY L. REV. I89, 190-93 (1983).

61 Gary S. Becker, A Theory of Social Interactions, 82 J. POL. ECON. 1063 (1974). For more detailed criticism of Becker's model, see EPSTEIN, supra note 4 I, at 22-23. 
model of inclusive fitness, given that siblings share on average one-half of their genes. In Becker's model, siblings cooperate only because of the threat that their parents will shift resources back and forth among them. His model therefore predicts much less cooperation between siblings than is observed in nature and does not explain why siblings do not often kill each other to monopolize their parents' attentions. Yet by the same token, Becker's model offers a powerful explanation of how individuals (or nations) in nonfamilial settings secure cooperation between groups that would otherwise be in conflict with one another, by offering some benefit to each group conditional on its cooperation with a common plan. Thus, the American and European strategy to achieve political harmony in Afghanistan promises aid only to those tribes and groups that cooperate with our stated objectives of achieving general stability and democracy within the nation.

It is possible to deviate from the basic assumptions of the standard model of self-interest in yet other ways. The general view of human preferences that I have described posits that preferences are absolute: more is better, for me, no matter what others have. But one of the most powerful trends in recent thought, also closely associated with Becker, has been the use of behavioral economics to undermine the assumption that people are guided by stable preferences in choosing among the various options presented to them. ${ }^{62}$ The modern assault has sought to find examples, drawn both from everyday life and from simple experiments, that confound the predictions normally drawn from the standard model of human preferences. ${ }^{63}$ One strand of this attack, developed extensively by the economist Robert H. Frank, argues (among other things) that people are moved less by their absolute wealth than by their relative position to some external reference group, without regard to such conventional considerations as envy or social status. ${ }^{64}$

The program in question strikes this reader as inherently implausible as an overall account of human behavior. To be sure, even the classical account of absolute preferences does not lead to the conclusion that individuals are steadfastly indifferent to the way they are treated in comparison with other persons. Individuals in a workplace, for example, are rightly concerned when their peers receive larger

62 See Gary S. Becker, The Economic Approach to Human BehaVior I4 (1976) ("[A]ll human behavior can be viewed as involving participants who [I] maximize their utility [2] from a stable set of preferences and [3] accumulate an optimal amount of information and other inputs in a variety of markets.") (enumeration added).

63 See, e.g., Behavioral LaW \& Economics (Cass R. Sunstein ed., 2000); RICHARD H. THALER, QUASI RATIONAL ECONOMICS (Ig9I).

64 See, e.g., Robert H. Frank, The Demand for Unobservable and Other Nonpositional Goods, 75 AM. ECON. REV. IOI (1985); Robert H. Frank, The Frame of Reference as a Public Good, 107 Econ. J. 1832 (1997); see also Richard H. McAdams, Relative Preferences, I02 YALE L.J. I (1992). 
raises than they do, for this disparity provides some powerful insight into the prospects of promotion within the firm and thus affects their absolute as well as their relative position. Nor does it make sense to doubt that individuals sometimes envy the success of others. Status often operates as a relative concept - if everyone is of high status, then no one is of high status - so the perception that the status of some persons within a group has increased often carries with it the negative implication that one's own status (and, by extension, one's prospects) has correspondingly diminished.

The position of Frank and likeminded scholars, however, goes beyond these behavioral responses and holds that individuals care as much about their relative wealth as they do about their absolute position, even when the issues of information and status described above are set aside. This position cuts deep into the traditional legal synthesis by broadening the concept of (negative) externality that in general justifies social intervention. According to the traditional accounts, the wages received by one worker are a matter to be decided between employer and employee. The implicit assumption is that these wage effects do not rank with pollution as proper targets for social control. But once it is assumed that individuals care as much or more about their relative position as they do about their absolute position, all bets are off. The decision of any employer to give a raise to one worker could easily be construed as creating a negative externality with respect to other workers in that firm (or indeed to any other workers anywhere). Accordingly, the workers who are left behind could claim that they are entitled to protection against these negative external effects. But if these workers are given parallel raises, yet another externality arises - higher-paid workers will now suffer losses in utility because the gap separating them from other workers has narrowed. In effect, all shifts in wage levels have external consequences that justify legal intervention. The consequences of this view are made explicit by Frank, in an article written with Cass Sunstein:

Assume that relative rather than absolute economic position is what most workers care about - that worker well-being would not be decreased by (say) a decrease in annual wages of $\$ 250, \$ 500$, or $\$ 1000$, so long as all workers face the same annual decrease. In that event, some nonwaivable terms, such as a right to job security, might be justified on the ground that the consequence of the new term is to decrease absolute income but to hold relative income constant, thus imposing little or no welfare loss on workers, while at the same time giving workers a substantial benefit, such as job security. ${ }^{65}$

65 Robert H. Frank \& Cass R. Sunstein, Cost-Benefit Analysis and Relative Position, 68 U. CHI. L. REV. 323, 373 (200I). 
This defense of nonwaivable terms works a major revolution in the law of contract and carries as one of its implications the abrogation of the contract at will. ${ }^{66}$ But this retreat from the conventional law of contract does not indicate what should go in its place, or indeed, whether any legal solution can remain viable once any decline in relative position is regarded as, in itself, a colorable basis for government intervention. Furthermore, this complex model does not seem empirically plausible. The economist Truman Bewley has collected detailed survey information that generally supports the position that workers react negatively to wage cuts even when other workers have taken similar cuts. The following responses were among those Bewley gathered:

People can't explain a pay cut at home, whereas if they are laid off they can draw unemployment benefits and look for new work. A pay cut is like a criticism or an insult. Pay is so closely associated with self-worth that a cut is taken personally.

A pay cut would be interpreted as a punishment, even if it were done across the board.

Morale suffers from a pay cut for psychic reasons. It says, "I am doing badly," even if everyone gets a pay cut. ${ }^{67}$

The "even if" clause undercuts the empirical claim that relative preferences dominate workplace decisions.

Bewley's basic empirical findings also make sense from a theoretical point of view. The quoted passage from Frank and Sunstein offers no hint as to the wage interval over which relative preferences will dominate absolute ones. In principle, we should have to build at the very least a model in which utility depends on both absolute and relative preferences as a function of the wage levels of these employees. Any such model is far less tractable than a simpler model that assumes absolute preferences govern and thus severs the negative link between the utility derived by one person and the wages paid to another. I think that the better way to approach legal scholarship is to avoid these complications, which require us to retool virtually every area of law in as yet indeterminable ways. The best advice is, as it were, to

66 For my response to this argument, see Richard A. Epstein, In Defense of the Contract at Will, 5 I U. CHI. L. REV. 947 (I984). The key elements of the defense are that the agreement is cheap to enforce and that it provides strong incentives for cooperation by both sides, as the threat to quit or fire tends to rein in threats from the other side. The arrangement also allows for a cheap redeployment of labor when market and technical changes require a quick revamping of the workforce.

67 Truman F. Bewley, Why Wages Don'T Fall DURING a Recession 175 (1999) (quoting three respondents). 
follow Sam in Casablanca and to assume that "the fundamental things apply." What matters is the sequence of the argument. As a general strategy of legal and social analysis, it is best to start simple. It is only when these "fundamental things" have palpably broken down that it becomes appropriate to introduce into the analysis more complex assumptions about human behavior, assumptions that appear to make the answer to every important inquiry indeterminate. Thus, our task as scholars is to identify and resolve the tradeoffs so common in human affairs.

At this point, an eager and idealistic reader may feel let down. One of the aspirations of legal scholarship is to find some magical insights that will allow us to transform large segments of society in ways that will improve the lot of us all. But for better or worse, our legal system does not give lawyers a lock on social innovation; nor does it place a single individual at the helm. Both inertia and confusion are endemic to our legal system. Within this environment, we should lower our sights and try to improve our overall reliability as analysts by stressing the incremental improvements that we can make, which again brings us back to the ubiquity of tradeoffs. The key to legal scholarship, in my view, lies in understanding why and how these tradeoffs should be made.

Taken seriously, this program is as ambitious as the list of tradeoffs is long. At the most fundamental level, the question is whether to opt for a simple system with low administrative costs or for one that seeks to fine-tune the incentives provided to various actors. I have generally tended to favor the former approach, but clearly this preference is a matter of degree given that the extreme position - no law at zero administrative cost - is a recipe for anarchy. 68 What is needed when evaluating any legal rule is a constant awareness of when additional refinement creates more grief than it is worth. This tradeoff constitutes, for example, a key consideration in the choice between at-will and for-cause rules in employment contracts, and it reappears countless times in the choices between negligence and strict liability, custom and reasonable care, and absolute and qualified immunity for public officials.

The theme of tradeoff also dominates elsewhere. In the current climate, it obviously defines the endless discussions about the tension between liberty and security in times of social and political unrest. More traditionally, one central question in the law of property concerns the optimal mix between private and common property. To what extent should we opt for regimes of exclusivity rather than regimes of (more or less) open access? How does one weigh the incentive

68 See Richard A. EPSTEIN, SIMPLE RULES FOR A COMPLEX WORLD 30-36 (1995). 
to produce, which rules of exclusive ownership foster, against the ability to use what has been created, which rules of open access facilitate? These same questions arise with regard to the allocation of open spaces; the creation of public highways and parks; the control of fishing and wildlife; the governance of rights in oil, gas, flowing water, and groundwater; and the creation of communications networks in the Internet age. Within intellectual property law, questions about the duration of copyrights, patents, and trade secrets are part of a broader debate over when inventions and literary works should become part of the public domain. Make the period too short, and the level of innovation will be too low. Make it too high, and the subsequent restrictions on use will be too great. It is of course quite impossible to balance these objectives in each individual case, but it is possible to make sensible arguments to the effect that the protection afforded copyrights should in general be longer than that afforded patents, where it is far more likely that multiple contestants are pursuing a single objective.

The same theme appears in connection with remedies for harmful activities. Broadly speaking, these remedies fall into two classes: those that enjoin an activity unless the party so enjoined can buy himself out of the injunction and those that impose damages but otherwise allow the activity to proceed. ${ }^{69}$ The key tradeoff here stems from the shortcomings of the aiternative approaches. Injunctive relief creates the risk that one side will hold out for an extortionate gain; the damage rule creates the risk that an individual may profit from his own wrongdoing by escaping liability after the fact, either through insolvency or departure from the jurisdiction. These defects have spurred extensive debate over the appropriate remedial instruments in both the public and private sectors. What measure of damages should be used when damages seem required? And what form of injunctive relief or government controls should prevent injury from occurring in the first place?

The program I have defined relates as much to intellectual elegance as it does to empirical work. My own view is that legal scholarship does its best work when it uses simple, consistent assumptions to tease out surprising implications from a wide range of social phenomena. Good legal scholarship does not lie, for the most part, in inventing exotic models of human behavior that are of limited relevance to con-

69 See Guido Calabresi \& A. Douglas Melamed, Property Rules, Liability Rules, and Inalienability: One View of the Cathedral, 85 HARV. L. REV. I089, II16-24 (1972). By the same logic, Calabresi and Melamed's insistence on the so-called "rule four" - which allows pollution to continue unless the polluted party buys his way out of the wrong - is ingenious but misguided. If ever implemented, such a rule would undermine the security of property rights. For my earlier criticism, see Richard A. Epstein, A Clear View of The Cathedral: The Dominance of Property Rules, IO6 YALE L.J. 2091 (1997). 
crete situations. There is much to dispute in all the areas of law that are part of the modern landscape, including environmental law, antidiscrimination law, antitrust and trade regulation, pensions, taxation, and family law. Each area raises distinctive questions of administration, but each is amenable to key insights on human behavior and social organization. Across the board, differences in approach often lead to strong differences in outcome. An emphasis on traditional accounts of human behavior points toward market solutions that maximize gains from trade and rely on free entry to discipline the behavior of wayward actors. But the more complex models of human behavior often (as with the contract at will), but not always, suggest a greater sphere for government intervention. Yet these more complex models are plausible only if we assume that institutions and practices that have endured over time and across cultures are fundamentally flawed for reasons that market participants just cannot grasp.

Custom, stability, and durability matter a lot in this world, and their virtues are frequently misunderstood and underrated. Praising these qualities does not imply an opposition to change and innovation, but only assumes that social and technical advances are more likely to take place in a relatively stable legal framework. Progress stems from invention and entrepreneurial activity, not from an inexorable expansion of the role of government. The search for intellectual novelty leads people to neglect and understate the power of traditional models to explain and systematize human behavior. The goal of legal scholarship should be to distill the few key assumptions that allow intelligent work to go forward. In the end, we shall do better if we take Sam's advice in Casablanca and recognize that "the fundamental things apply." 